\title{
PHENOMENOLOGY STUDY: CAREGIVER EXPERIENCE IN NURSING ELDERLY WITH SELF-CARE DEFICIT AT PANTI WERDHA PANTI PANGESTI LAWANG
}

\author{
Ellia Ariesti', Retty Ratnawati ${ }^{2}$, Retno Lestari ${ }^{3}$ \\ ${ }^{1}$ Nursing Academy of Panti Waluya Malang \\ ${ }^{2,3}$ Master of Nursing ProgramFaculty Of Medicine Universitas Brawijaya
}

\begin{abstract}
Elderly is the last stage of human growth development and often related to body function derivation which cause helplessness. Elderly whom stay at nursing home, would depends their self-care to the caregiver because their family could not have abillity to nursing them. This research aim was to explore the caregiver experienced in nursing elderly with self-care deficit at Panti Werdha Panti Pangesti Lawang. Qualitative research design were used, with intepretive phenomenology aprroachment. Data collection technique was depth interview method and semistructured interview guidelines were used. This researh generated ten themes: still fulfilled elderly self-care who were unable to met their necessity, gratefull feeling and not burdened when nursing the elderly, pity and learnt to be patient, tried to aprreciate elderly by didn't show displeasing expression and show responsibility, became angry and force the elderly during nursing period, tried to fulfill all elderly necessities, a lot of energy were needed and teamwork, elder people had their own behavior, willingness to nurse the elderly better and more passionate, were called to nurse the elderly similar to their parents. This condition would lead to frustation, burdened feeling, exhaustion, and stress in caregiver. Conditions above need further prevention from health care provider.
\end{abstract}

Key words: Caregiver, Elderly, Self-care Deficit

\begin{abstract}
ABSTRAK
Masa lansia sering diidentikkan dengan masa penurunan berbagai fungsi tubuh dan berdampak pada ketidakberdayaan. Pada saat lansia tinggal di panti werdha dikarenakan ketidakmampuan keluarga untuk mengurus, dan bergantung pada pertolongan orang lain, perawatan lansia dalam pemenuhan perawatan diri lansia digantikan oleh caregiver yang ada di panti werdha. Penelitian ini bertujuan untuk mengeksplorasipengalaman caregiverdalam merawat lansia dengan defisit perawatan diri di Panti Werdha Pangesti Lawang.Desain penelitian ini adalah penelitian kualitatif, dengan pendekatan fenomenologiintepretif. Pengumpulan data menggunakan metode wawancara mendalam dengan panduan wawancara semi terstruktur yang melibatkan tujuh partisipan. Penelitian ini menghasilkan sepuluh tema meliputi: tetap memenuhi perawatan diri lansia yang tidak mampu, merasakan senang dan tidak terbebani saat merawat lansia, merasakan kasihandan belajar bersabar saat merawat lansia, menghargai lansia dengan tidak menunjukkan rasa jijik dan bertanggungjawab saat merawat lansia, menjadi emosi dan memaksa lansia saat dilakukan perawatan, berusaha memenuhi semua kebutuhan lansia, merasakan perlu tenaga yang besar dan kerjasama saat merawat lansia, merasakan perilaku dan keinginan lansia yang semaunya sendiri, keinginan merawat lansia yang lebih baik dan lebih sabar lagi, serta terpanggil untuk merawat lansia seperti orang tua sendiri. Mengingat dampak yang muncul dari kondisi ini bisa menyebabkan kejenuhan, frustasi, beban, dan stress yang dialami oleh caregiver, maka diperlukan dukungan dari tenaga kesehatan agar tidak terjadi dampak negatif.
\end{abstract}

Kata kunci: caregiver, lansia, defisit perawatan diri

Jurnal Ilmu Keperawatan Vol. 6, No. 1 Mei 2018. Korespondensi : Ellia Ariesti. AKPER Panti Waluya. Jalan Yulius Usman No. 62 Malang. Email: ellianathanael@gmail.com. No. Hp:083834696761 


\section{PENDAHULUAN}

Masa lanjut usia merupakan tahap akhir dari tahapan perkembangan kehidupan manusia. Di masyarakat Indonesia masa lansia sering diidentikkan dengan masa penurunan berbagai fungsi tubuh dan berdampak pada ketidakberdayaan (Syam'ani, 2011).Terjadinya penurunan fungsi kognitif menyebabkan semakin memburuknya ketidakmampuan lansia dalam melakukan aktifitas normal sehari-hari, sehingga menyebabkan terjadinya ketergantungan terhadap orang lain untuk merawat diri sendiri (care dependence) (Reuser et al., 2010).

Defisit perawatan diri merupakan suatu kondisi pada seseorang yang mengalami penurunan kemampuan dalam melakukan aktivitas perawatan diri secara mandiri seperti mandi, berpakaian/berhias, makan, dan BAB/ BAK (Fitria, 2009).Jika kondisi defisit perawatan diri berlanjut maka bisa menimbulkan dampak baik secara fisik maupun psikologis. Nordenfelt (2009) menyatakan bahwa ketikaseseorang tidak lagi mampu merawat dirinya sendiri secara mandiri, dapat menyebabkan rasa rendah diri, menjadi tergantung pada caregiver dalam kehidupan sehari-hari dan hal itu dapat menjadi titik kritis dalam kehidupan lansia.

Beberapa lansia diharuskan untuk tinggal di panti werdha dikarenakan berbagai macam alasan diantaranya seperti ketidakmampuan keluarga untuk mengurus, dan bergantung pada pertolongan orang lain membuat keluarga akan mengirim lansia ke panti werdha (Andini \& Supriyadi, 2013). Peranan keluarga dalam perawatan lansia terutama dalam pemenuhan perawatan diri lansia dengan sendirinya akan digantikan oleh caregiver yang ada di panti werdha.

Caregivermemberikan perawatan kepada lansia bisa penuh waktu, paruh waktu baik secara fisik dan emosional.Hanya sedikit orang yang siap untuk tanggung jawab dan tugas-tugas yang terlibat dalam merawat lansia karena stres yang terlibat di dalamnya. Lecovich E (2008) menyatakan bahwa caregiver memberi bantuan dan perawatan mulai dari membantu tugas sehari-hari seperti mandi, berpakaian, makan, memindahkan lansia, membawa kembali ke tempat tidur, memberikan obat, menjaga lansia, memberikan dukungan emosional dan begitu banyak hal lain. Semua kegiatan tersebut dapat memakan waktu, emosional, fisik dan psikologis.Hal Ini kemudian berkontribusi banyak terhadap stres pada caregiver (Losada et al, 2009). Penelitian ini bertujuan untuk mengeksplorasipengalaman caregiverdalam merawat lansia dengan defisit perawatan diri di Panti Werdha Pangesti Lawang.

\section{METODE}

Desain penelitian ini adalah penelitian kualitatif, dengan pendekatan fenomenologi intepretif. Partisipan yang terlibat dalam penelitian ini sejumlah tujuh orang yang sesuai dengan kriteria inklusi yaitu memiliki pengalaman bekerja sebagai caregiverminimal 1 tahun, sehat jasmani dan rohani, mampu menceritakan pengalamannya secara lisan dengan baik, bersedia menjadi partisipan yang ditentukan dengan purposive sampling. Pengumpulan data dilakukan dengan wawancara mendalam (indepth interview) menggunakan panduan wawancara semi terstruktur. Selama wawancara peneliti juga 
menggunakan catatan lapangan (field note). Setelah data terkumpul peneliti menggunakan Interpretative Phenomenological Analysis (IPA) dalam proses analisa data.

\section{HASIL PENELITIAN}

Peneliti telah mengidentifikasi 10 tema dalam penelitian ini yang meliputi: tetap memenuhi perawatan diri lansia yang tidak mampu, merasakan senang dan tidak terbebani saat merawat lansia, merasakan kasihandan belajar bersabar saat merawat lansia, menghargai lansia dengan tidak menunjukkan rasa jijik dan bertanggungjawab saat merawat lansia, menjadi emosi dan memaksa lansia saat dilakukan perawatan, berusaha memenuhi semua kebutuhan lansia, merasakan perlu tenaga yang besar dan kerjasama saat merawat lansia, merasakan perilaku dan keinginan lansia yang semaunya sendiri, keinginan merawat lansia yang lebih baik dan lebih sabar lagi, serta terpanggil untuk merawat lansia seperti orang tua sendiri. Adapun rincian dari kesepuluh tema yang diperoleh akan dibahas sebagai berikut:

Tetap memenuhi perawatan diri lansia yang tidak mampu

Tetap memenuhi perawatan diri lansia adalah hasil akhir dari ketidakmampuan lansia dalam memenuhi perawatan dirinya karena sakit dan faktor usia. Berikut akan dibahas subtema yang muncul berdasarkan tema tersebut, yaitu:

"..mungkin sebelumnya dia melakukan secara mandiri, tetapi berhubung ada keterbatasan entah itu dari penyakitnya, entah itu dari faktor usianya sendiri sehingga mereka mengalami penurunan kemampuan untuk melakukan aktifitasnya." (P1)

Pernyataan diatas menunjukkan bahwa partisipan memahami penyebab lansia mengalami defisit perawatan diri karena faktor penyakit yang diderita lansia serta karena faktor usia lansia sendiri yang menyebabkan lansia mengalami defisit perawatan diri.

\section{Merasakan senang dan tidak terbebani saat merawat lansia}

Tema perasaan tersebut mewakili perasaan partisipan pada saat merawat lansia. Berikut akan dibahas subtema pertama yang muncul berdasarkan tema tersebut:

"...Ya..kalau saya sendiri merasa senang jadi perawat disini itu karena bisa lebih mengenal mereka, kalau di rumah sakit kan pasienya selalu berganti-ganti ya, kalau bedanya disini itu pasienya tetep itu saja." (P3)

Pernyataan diatas menunjukkan bahwa partisipan merasakan senang dan bangga saat mereka bisa mengenal lansia yang dirawatnya.

Sub tema kedua yaitu merasa tidak terbebani pada saat merawat lansia, Berikut contoh kutipan ungkapan partisipan:

"Nahh..itu..kalau menurut saya itu gini..lansia itu kan seperti anak kecil, kita itu seperti kayak momong..kita itu seperti mengajak bercanda, bergurau kayak gitu..kita mengajak bermain gitu lah.. Sama sekali gak 
ada beban..dianggap fine-fine saja

(baik-baik saja)". (P4)

Pernyataan diatas menunjukkan bahwa partisipan merasakan perubahan yang terjadi pada lansia sekarang memiliki karakter dengan anak kecil yang perlu diperhatikan, diajak bercanda sehingga tidak ada beban saat merawat lansia karena menurut partisipan saat lansia tidak bisa merawat dirinya sendiri mereka merasa kasihan kalau lansia tidak terpenuhi perawatan dirinya.

\section{Merasakan kasihan dan belajar bersabar saat merawat lansia}

Merasakankasihandanbelajarbersabar saat merawat lansiaadalah hasil akhir dari perasaan partisipan yaitu merasa kasihan jika lansia tidak terawat, perasaan jengkel saat lansia sulit dirawat, serta belajar sabar dan menahan emosi. Berikut akan dibahas subtema pertama yang muncul berdasarkan tema tersebut:

"Yang saya rasakan ya itu..merasa kasihanaja..maksutnya..kalau kita di posisi beliau maksutnya di posisi lansia itu, kita kan juga pasti..ahh..masak kita merasa kayak gitu dak ada yang bantu terus kita kalau di posisinya beliau masak orang lain gak bisa bantu kita..". (P4)

Pernyataan diatas menunjukkan bahwa partisipan merasakan perasaan sedih jika lansia tidak mampu merawat dirinya meskipun lansia diberi umur panjang, partisipan juga merasakan jika suatu saat masa tuanya mengalami hal serupa dengan lansia yang dirawat sekarang, sehingga partisipan merasa kasihan kalau lansia menjadi terlantar atau tidak terpenuhi perawatan dirinya.
Sub tema kedua perasaan jengkel saat lansia sulit dirawat, menggambarkan perasan partisipan saat merawat lansia yang mengalami defisit perawatan diri. Berikut contoh kutipan ungkapan partisipan:

“..mbah-mbahnya yang cerewet itu paling ya mengeluh itu saja tapi dak pernah langsung dimasukan ke hati..soalnya kalo dimasukkan ke hati gak mungkin bisa lama disini..paling keluhanya ya itu Cuma sebel-sebel sebentar..". (P1)

Pernyataan diatas menunjukkan bahwa partisipan merasakan perasaan jengkel atau marah saat lansia yang dirawatnya tidak menurut, atau memukul. Kondisi lansia biasanya mengalami gangguan pada afek emosi yang cenderung tidak sesuai antara apa yang dirasakan atau suasana hati dengan situasi saat ini yang dialami. Perilaku tidak stabil juga dapat ditunjukkan oleh lansia, tidak hanya kecenderungan pasif yang mengikuti afek perasaannya, namun kadangkala juga menunjukkan adanya perilaku bermusuhan atau agresif. Sikap agresif ini dapat ditunjukkan dengan sikap bermusuhan baik secara fisik melalui tindakan yang kasar maupun secara verbal yaitu melalui umpatan-umpatan kasar.

Sub tema ketiga yaitu belajar sabar dan menahan emosi. Berikut contoh kutipan ungkapan partisipan:

" Kalau saya pribadi buk ya..kayak nelongso..(sedih) dlam hati itu..lawong aku iki lo ngrumati wong dekne BAB..kok kayak gitu (la saya ini lo merawat, dia itu penuh $B A B)$..dalam hati ya sedih buk..kayak gitu tadi kita niat baik kok ya 
sulit..kan gitu a buk..yak apa ya caranya wong saya sudah halus kok sulit..kadang dalam hati ya nelongso..". (P7)

Pernyataan diatas menunjukkan bahwa perasaan partisipan tidak mudah terbawa emosi dan lebih sabar saat merawat lansia yang mengalami defisit perawatan diri. Kondisi sedih bisa dialami oleh caregiver ketika perilaku lansia menyulitkan caregiver untuk merawat. Ketika perilaku lansia sulit untuk dikendalikan, caregiver bisa merasa jengkel bahkan sedih dan merasa ini adalah situasi yang tidak menyenangkan bagi dirinya.

\section{Menghargai lansia dengan tidak menunjukkan rasa jijik dan bertanggungjawab saat merawat lansia}

Didapatkan empat sub tema yaitu menjaga perasaan lansia dengan tidak menunjukkan rasa jijik, menghargai lansia saat merawatnya, menyadari tugas yang harus dilakukan, danmerawat dengan sabar dan tidak emosi. Berikut akan dibahas subtema pertama yang muncul berdasarkan tema tersebut:

" Duluu..awalnya..awal belum terbiasa kan ada perasaan jijik, soale kan berhubungan dengan kayak gitugitu itu buk..lama-lama kelamaan itu ya sudah biasa..". (P1)

Pernyataan diatas menunjukkan bahwa sikap partisipan biasa saja dan tidak menunjukkan sikap jijik saat merawat lansia yang mengalami defisit perawatan diri. Faktor usia yang terjadi pada lansia kerap kali mengakibatkan kelemahan di otot perkemihan ataun eliminasi bowelnya. Caregiver melaporkan adanyaketidakmampuan lansia dalam mengendalikan BAB atau BAK nya. Kondisi ini juga ditunjang oleh penurunan fungsi kognitif lansia, sehingga menyebabkan mereka tidak menyadari perbuatan yang dilakukan, sehingga pada saat seperti ini caregiver harus mennujukkan sikap sabar dan tidak jijik.

Sub tema kedua menghargai lansia saat merawatnya, Berikut contoh kutipan ungkapan partisipan:

"Kalau saya sendiri ya wes..tak iyaa...iyaaa..diem seperti tak turuti maunya, tapi kalau yang lain itu ada dia nyocot (cerewet)..ditambahi nyocot (cerewet) lagi biasanya kan ada..kalau saya wes timbang diladeni dak mari-mari (dak selesai-selesai) mending dituruti ae wes..". (P1)

Perilaku tidak stabil yang ditunjukkan lansia, kerapkali menyebabkan lansia menjadi kasar baik secara verbal atau melalui tindakan-tindakan yang kasar, saat menghadapi kondisi yang demikian maka sikap caregiver dituntut untuk tetap menghargai keinginan lansia dan bisa memprioritaskan lansia mana terlebi dulu yang mau dirawatnya. Hal ini dilakukan caregiver guna menghindari dampak negatif yang bisa muncul.

Sub tema ketiga menyadari tugas yang harus dilakukan. Berikut contoh kutipan ungkapan partisipan:

“..tapi ya diingat lagi wong kita disini memang untuk bantu itu..ya kembali lagi ke diri sendiri wong kerjanya memang kayak gini..ya memang ini yang perlu dilakuin..". (P1) 
Caregiver menjalankan peran intinya yaitu memberikan bantuan secara langsung dalam sehari-hari sesuai dengan kebutuhan lansia. Sikap caregiver yang menunjukkan kesadaran akan tugas dan tanggung jawab ini dapat menghindarkandampak negatif yang muncul saat melakukan perawatan lansia dengan defisit perawatan diri.

Sub tema keempat yaitu merawat dengan sabar dan tidak emosi. Berikut contoh kutipan ungkapan partisipan:

" lya buk..emosi dan keegoisan kita harus tetap kita jaga buk ". (P7)

Sikap sabar dan tidak menunjukkan emosi saat merawat lansia dengan defisit perawatan diri diperlukan. Hal ini bisa menjadi dorongan bagi caregiver untuk menjalankan aktivitas perawatan bagi lansia.

\section{Menjadi emosi dan memaksa lansia saat dilakukan perawatan}

Berikut akan dibahas subtema pertama yang muncul berdasarkan tema tersebut:

" Kalau kejadiannya apa ya buk ya..kalau lansia itu agak berontak tadi, kita juga itu..udah tenaganya kurang terus lansianya juga berontak jadi kita agak mau emosi dikiittt. ". (P4)

apa kok bapak ini mukul?gitu..". (P5)

Pada saat merawat lansia dengan defisit perawatan diri, mereka memerlukan perhatian khusus dan ekstra, apabila caregiver tidak mampu melakukan untuk melakukannya maka dapat muncul sikap emosi. Terlebih jika perilaku lansia juga negatif.
Sub tema kedua memaksa agar lansia mau dirawat. Berikut contoh kutipan ungkapan partisipan:

" lya..agak memaksa, kalau yang bisa diajak bicara kan kita bisa membujuk, kalau yang seperti itu kan sudah dak bisa dibujuk. Kalau dak ngatasi orang satu ya harus orang dua ". (P5)

Ketidakmampuan lansia dalam mengontrol perilakunya yang terjadi pada lansia, ditunjukkan dengan tindakantindakan yang sulit dikendalikan, lemahnya pengendalian diri kerapkali ditunjukkan dengan perilakun yang semaunya sendiri. Kondisi ini akan menyulitkan caregiver untuk merawat lansia, sehingga kadang kala diperlukan paksaan saat merawat lansia.

\section{Berusaha memenuhi semua kebutuhan Iansia}

Ada 3 sub tema yaitu perawatan secara fisik terhadap lansia, dukungan emosi terhadap lansia, serta peran kerjasama dan kepedulian. Berikut akan dibahas subtema pertama yang muncul berdasarkan tema tersebut:

" Kalau perawatan diri itu dari memandikan, mencuci rambut, terus menggosok gigi, memotong kuku, terus apa namanya rendam kaki terus ganti baju mengganti pampers seperti itu..menyisiri, pake bedak itu semua kita.. Yaa...yang merawat ". (P3)

Saat melakukan perawatan pada lansia, caregiver memenuhi kebutuhan fisik lansia dengan defisit perawat diri. Kebutuhan fisik ini mencakup kebutuhan makan dan minum, 
mandi, berpakaian dan BAB serta BAK. Pemenuhan perawatan diri ini ditunjukkan mulai dari menyiapkan makan dan minum, membantu menyuapi, hingga memastikan makanan tersebut dimakan oleh lansia. Caregiver juga menyiapkan kebutuhan mandi dan memandikan sampai menganti pakaian hal ini penting dilakukan agar lansia tetap merasa nyaman dengan kondisi tubuh yang bersih, walaupun kadang perilaku lansia yang terkadang menolak untuk dimandikan. Gangguan inkontinensia terjadi juga pada lansia, sehingga caregiver perlu memakaikan pempers atau popok pada lansia serta membantu $B A B$ dan BAK pada lansia yang masih bisa mengontrol fungsi $B A B$ dan $B A K$ nya.

Sub tema kedua dukungan emosi terhadap lansia. Berikut contoh kutipan ungkapan partisipan:

"Ya dak..dia kan mestinya dibujuki (dibohongi), dibujuk supaya bisa dirawat terus kalau makan ya gitu..kadang orang yang seperti itu jarang mau makan, kita kan juga mau membujuk dengan sabar agar orangnya mau makan mau minum ". (P5)

Kelemahan kemampuan kognitif yang terjadi pada lansia salah satunya adalah tidak dapat menentukan atau memutuskan suatu pilihan, oleh karena itu dalam memenuhi kebutuhannya caregiver perlu mengambil alih atau menentukan untuk perawatan hariannya.

Sub tema ketiga yaitu peran kerjasama dan kepedulian. Berikut contoh kutipan ungkapan partisipan:
"Kalau menurut saya lebih efektif kalau kita berkelompok tadi..jadi kita dak terlalu banyak menguras tenaga kayak satu ruangan satu orang..itu full menguras tenaga..". (P3)

Kondisi fisik lansia yang menurun juga menjadi hal yang perlu diperhatikan saat melakukan tindakan perawatan pada lansia. Adanya permasalahan butuhnya perawatan ektra, perlunya bantuan orang lain dalam merawat juga perlu diperhatikan oleh caregiver. Kondisi fisik yang sehat, hal ini juga penting untuk caregiver karena dengan kondisi fisik yang sehat dapat menunjang aktifitas perawatan harian. Kekuatan bantuan dari caregiver juga memiliki manfaat bagi caregiver sehingga diperlukan kemampuan kerjasama antar caregiver.

\section{Merasakan perlu tenaga yang besar dan kerjasama saat merawat lansia}

Sub temanya yaitu membutuhkan banyak tenaga dan perlunya kerjasama. Berikut akan dibahas subtema yang muncul berdasarkan tema tersebut:

"..kalau hambatannya kan yang kalo penurunan itu kan memerlukan ekstra tenaga buk...mungkin hambatannya itu dengan temantemannya saja, mungkin kurang komunikasinya saja..". (P4)

Kondisi fisik lansia yang menurun juga menjadi hal yang perlu diperhatikan saat melakukan tindakan perawatan pada lansia. Adanya permasalahan butuhnya perawatan ektra, perlunya bantuan orang lain dalam merawat juga perlu diperhatikan oleh caregiver. Kekuatan bantuan dari caregiver juga memiliki manfaat bagi caregiver 
sehingga diperlukan kemampuan kerjasama antar caregiver.

\section{Merasakan perilaku dan keinginan lansia yang semaunya sendiri}

Merasakan perlu tenaga yang besar dan kerjasama saat merawat lansia adalah sub tema dari tema tersebut. Berikut akan dibahas subtema yang muncul berdasarkan tema tersebut:

"Kalau berontak itu biasanya marah-marah..terus diajak rawatan itu dak mau, ditunggu terus..habis ditunggu terus dibujuk lagi..biasanya masih marah-marah, terus ditunggu lagi sampai dia mau..". (P5)

Ketidakmampuan lansia dalam mengontrol perilakunya yang terjadi pada lansia, ditunjukkan dengan tindakantindakan yang sulit dikendalikan, lemahnya pengendalian diri kerapkali ditunjukkan dengan perilaku yang semaunya sendiri. Kondisi ini akan menyulitkan caregiver untuk merawat lansia.

\section{Keinginan merawat lansia yang lebih baik dan lebih sabar lagi}

Sub tema dari tema ini yaitu menjadi sabar, berharap pelayanan yang terbaik untuk lansia, dan berharap lansia lebih mandiri merawat dirinya. Berikut akan dibahas subtema pertama yang muncul berdasarkan tema tersebut:

" Harapan saya ya semoga saya dikasih lebih sabar lagi...terus apa ya soalnya kan memang kerja disini jujur ya buk ya..gak kayak ditempat lain. Selain dibutuhkan tenaga, kesabaran juga soalnya setiap hari yang ditemui kan orang-orang itu aja, ya semoga aja lebih sabar." (P1)
Pernyataan diatas menunjukkan bahwa dengan merawat lansia dapat membuat partisipan menjadi pribadi yang lebih sabar lagi, karena berbagai kondisi yang dialami oleh lansia dapat menimbulkan efek secara psikologis tersendiri bagi caregiver nya.

Sub tema kedua berharap pelayanan yang terbaik untuk lansia. Berikut contoh kutipan ungkapan partisipan:

"Yang saya harapkan itu dari hari ke hari itu lebih baik..ada peningkatan ya baik dari segi lingkungan, kesehatan, lansianya.. istilahnya walau kita merawat tapi kalau mereka terjamin itu..jadi senang..". (P2)

Anggota team perawatan yang juga dapat digunakan sebagai sumber dukungan dalam merawat lansia. Oleh karenanya rasa saling memahami antar caregiver juga diperlukan dalam perawatan lansia dengan defsit perawatan diri. Kemampuan kerjasama juga diperlukan agar tidak menjadikan beban tersendiri untuk caregiver yang lain, seolaholah semua adalah tanggung jawabnya sendiri.

Sub tema ketiga yaitu berharap lansia lebih mandiri merawat dirinya. Berikut contoh kutipan ungkapan partisipan:

" Kalau harapan saya itu.. kalau lansia itu kan ada yang mengalami penurunan perawatan diri, tapi paling dak itu dia mempunyai suatu keinginan mana yang ia masih bisa melakukan, soalnya ada lansia yang dia masih bisa tapi dia malas..pengen saya itu dia belajar..". (P3)

Pernyataan diatas menunjukkan bahwa partisipan mengharapkan lansia untuk tetap 
termotivasi dalam merawat dirinya, sehingga lansia tidak menjadi terlantar atau tidak terpenuhi perawatan dirinya.

\section{Terpanggil untuk merawat lansia seperti orang tua sendiri}

Sub temanya yaitu seperti keluarga sendiri, menjadi panggilan merawat, dan mempunyai ilmu dan pengalaman yang lebih. Berikut akan dibahas subtema pertama yang muncul berdasarkan tema tersebut:

"Ya perasaannya gimana lagi..wong dari awalnya saya sudah merasa itu sudah bukan menjadi beban, ya mau gak mau saya anggap ini orang tua saya sendiri, saya rawat-rawat sendiri jadi mau gak mau ya ini saya anggap orang tua saya sendiri ". (P4)

Pernyataan diatas menunjukkan bahwa partisipan saat merawat lansia menganggap lansia seperti orang tuanya sendiri, sehingga tidak membatasi mereka saat memberikan perawatan pada lansia.

Sub tema kedua menjadi panggilan merawat, berikut contoh kutipan ungkapan partisipan: "..jadi pedoman saya kerja itu ya pengabdian sama sudah ditakdirkan seperti ini ". (P6)

Pernyataan diatas menunjukkan bahwa partisipan saat merawat lansia menganggap bahwa mereka mandapat panggilan untuk merawat, sehingga tidak membatasi mereka saat memberikan perawatan pada lansia.

Sub tema ketiga yaitu mempunyai ilmu dan pengalaman yang lebih, berikut contoh kutipan ungkapan partisipan:

" Maknanya itu ya..saya itu bisa kalau ada orang minta bantu dirawat dirumah itu saya bisa..apalagi kalau orang tua sakit saya bisa merawatnya. Itu maknanya, bisa mandirilah dalam merawatnya..". (P6)

Pernyataan diatas menunjukkan bahwa partisipan saat merawat lansia mereka mendapatkan ilmu dan pengalaman yang bisa mereka gunakan untuk menolong atau membantu orang lain.

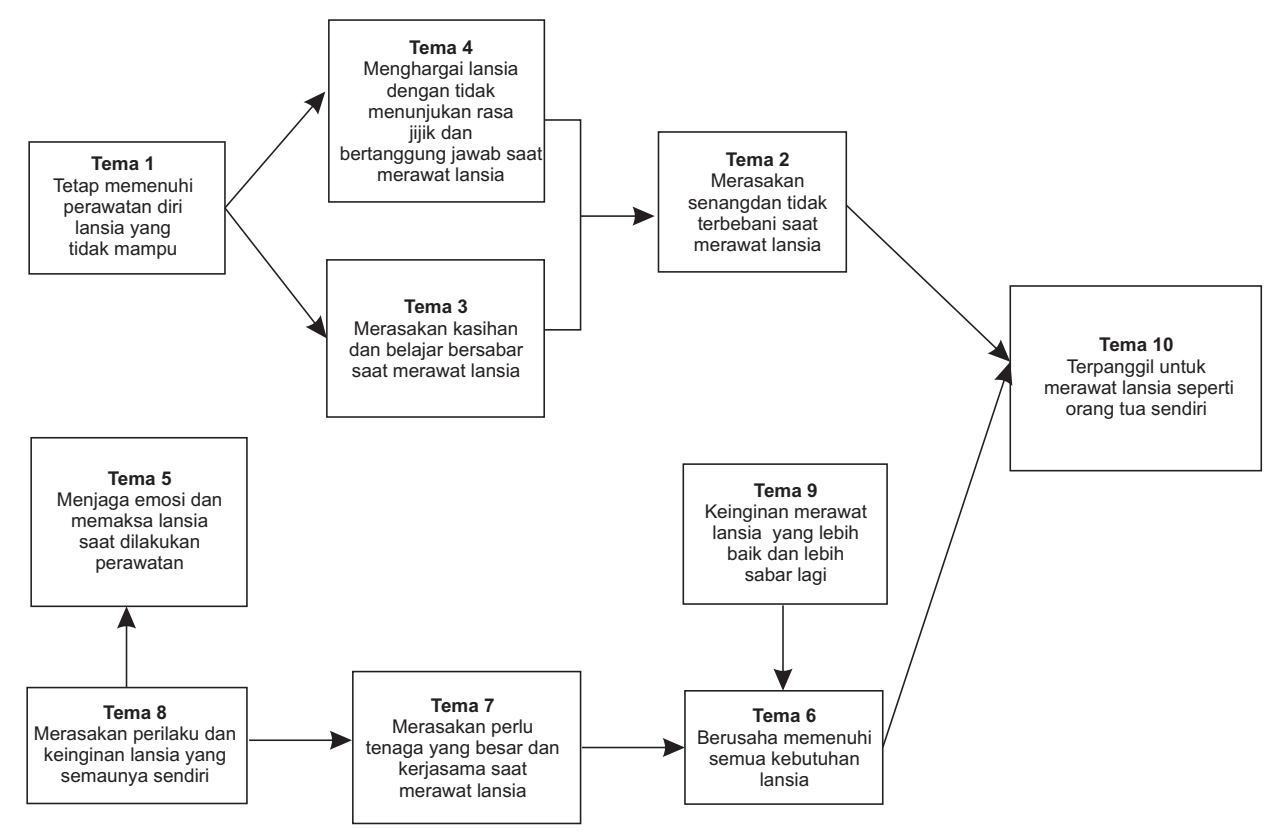

Skema 1. Interaksi antar tema 


\section{PEMBAHASAN}

Tetap memenuhi perawatan diri lansia yang tidak mampu

Makna yang didapat dari tema ini adalah bagaimana caregiver memahami dan menyadari akan perubahan kondisi yang dialami oleh lansia sehingga menyebabkan lansia terganggu dalam kemampuan perawatan dirinya. Pemahaman akan perubahan yang terjadi pada lansia diperoleh dari pikiran, pandangan tentang kondisi defisit perawatan diri, dan melibatkan perasaan caregiver saat melakukan interaksi perawatan sehari-hari dirumah. Perawatan lansia yang cenderung memiliki karakteristik long term care dan full time menjadikan caregiver dituntut mampu beradaptasi terhadap perubahannya. Oleh karena itu pemahaman awal caregiver tentang defisit perawatan diri dapat menjadi acuan terhadap apa yang harus dilakukan, bagaimana perubahan kondisi yang terjadi, dan perasaan apa yang muncul pada saat menghadapi lansia dengan defisit perawatan diri. Pemahaman tersebut penting sebagai penguat pada saat melakukan tindakan perawatan yang akan diberikan pada lansia dengan defisit perawatan diri agar semangat caregiver dalam merawat lansia tetap kokoh.

Dari hasil penelitian Tseng $\mathrm{CN}$, et. al (2015) menjelaskan bahwa caregiver atau caregiver menggunakan berbagai strategi untuk menghadapi lansia dengan inkontinensia, meskipun pada awalnya mereka kurang pengetahuan dan keterampilan yang diperlukan untuk memberikan perawatan inkontinensia. Salah satu strategi yang dapat dilakukan adalah dengan merawat penuh kasih sayang. Kasih menyatukan orang-orang di masa-masa sulit dan merupakan dasar untuk membangun hubungan manusia yang dapat meningkatkan kesehatan fisik dan mental (Gilbert, 2010).

\section{Merasakan senang dan tidak terbebani saat merawat lansia}

Tema kedua dari penelitian ini adalah caregiver merasakan senang dan tidak terbebani saat merawat lansia. Perasaan senang ini dapat diartikan sebagai kondisi dimana seseorang merasa puas dan lega, tanpa rasa susah dan kecewa saat melakukan suatu tindakan (KBBi.web.id) yang merupakan ungkapan perasaan caregiver saat merawat lansia dengan defisit perawatan diri.

Hermanns dan Smith (2012)melaporkan bahwa sebagian besar caregiveryang melakukan tidak memiliki pengalaman perawatan sebelumnya, tetapi mereka berkomitmen untuk belajar bagaimana melakukan tugas-tugas yang diperlukan untuk memberikan perawatan bagi penerima perawatan mereka.Selain itu, semua peserta berkomitmen untuk memberikan perawatan yang terbaik untuk penerima perawatan mereka.Semua peserta bersedia untuk belajar, dan kemudian belajar tindakan spesifik / tugas yang diperlukan untuk perawatan yang lebih baik untuk kebutuhan individu penerima perawatan mereka.

\section{Merasakan kasihandan belajar bersabar saat merawat lansia}

Respon dalam bentuk perasaan dalam pandangan kesehatan jiwa merupakan bagian dari penilaian individu terhadap stressor yang dialami. Penilaian ini menjadi jawaban atau tanggapan terhadap stimulus 
yang muncul. Penilaian tersebut bisa bermacam-macam tergantung stressor yang datang (Stuart, 2015). Hasil penelitian yang menunjukkan partisipan merespon stimulus dalam bentuk perasaan kasihan dan belajar bersabar menunjukkan stimulus yang dialami merupakan hal yang membuat menjadi sedih.

Pengalaman sehari-hari (meliputi tantang anda dan tugas) bersama lansia membuat caregiver memahami apa yang dibutuhkan dan yang tidak disukai oleh para lansia, dikarenakan intensitas interaksi antara caregiver dan lansia yang cukup padat. National Alliancefor Caregiving (2009) juga menyatakan bahwa pengalaman sehari-hari yang dialami caregiver memiliki hubungan yang positif.

\section{Menghargai lansia dengan tidak menunjukkan rasa jijik dan} bertanggungjawab saat merawat lansia

Tema keempat dari penelitian ini adalah menghargai lansia dengan tidak menunjukkan rasa jijik dan bertanggungjawab saat merawat lansia dengan defisit perawatan diri. Ketika proses penuaan manusia dimulai, banyak tugas harian menjadi lebih sulit untuk dilakukan oleh lansia, sehingga mereka menjadi tergantung pada orang lain. Dalam hal ini pada orang lain yang bisa membantu mereka yaitu keluarga atau orang lain yang bekerja untuk membantu lansia, yang bertanggung jawab untuk lansia dan memberikan bantuan kepada mereka.

Hasil penelitian Sulistyowati (2012) menyatakan bahwa peran perawat sebagai care provider harus dilaksanakan secara komprehensif atau menyeluruh, tidak hanya berfokus pada tindakan promotif, tetapi juga pada tindakan preventif seperti pelaksanaan kebersihan diri pada pasien, karena melakukan kebersihan diri pada pasien termasuk dalam standar kompetensi perawat dalam pelaksanaan asuhan keperawatan.

\section{Menjadi emosi dan memaksa lansia saat dilakukan perawatan}

Tema kelima dari penelitian ini adalah menjadi emosi dan memaksa lansia saat dilakukan perawatan. Beban caregiver didefinisikan sebagai tekanan-tekanan mental atau beban yang muncul pada orang yang merawat lansia, penyakit kronis, anggota keluarga atauorang lain yang cacat.

Studi juga menunjukkan bahwa salah satu alasan penelantaran pada lansia adalah stres yang dialami caregiver (Okoye, 2011).Okoye, 2011 melaporkan bahwa perawat yang merawat lansia dirumah cenderung terisolasi dari kontak normal sehari-hari.Isolasi dapat menyebabkan depresi dan kecemasan, yang pada gilirannya meningkatkan stres.Perasaan depresi bisa menjadi masalah serius bagi beberapa caregiver.

\section{Berusaha memenuhi semua kebutuhan lansia}

Merawat lansia yang tinggal di panti memerlukan perawatan yang lama dan butuh perhatian penuh, hal ini berkaitan dengan kondisi lansia yang mengalami penurunan terhadap kemampuan perawatan dirinya, karena faktor usia atau penyakit yang dideritanya. Caregiver cenderung memiliki hubungan yang lebih dekat dan berkewajiban merawat lansia, mereka juga memiliki peran serta fungsi tertentu dalam sistem. 
Bagaimanapun juga lansia dengan defisit perawatan diri membutuhkan perawatan yang lama dan memerlukan pengawasan, makna dari tema tindakan caregiver adalah caregiver dituntut mampu memenuhi kebutuhan perawatan diri lansia dan mereka merupakan potensi yang dapat menjawab kebutuhan perawatan serta pengawasan lansia, namun tindakan yang dilakukan tentunya juga harus secara tepat. Tugas caregivermemberikan perawatan holistik, mengatasi masalah fisik (mengurangi rasa sakit, memberikan obat), tetapi juga mengatasi masalah emosional dan memastikan bahwa semua kebutuhan terpenuhi (Zamanzadeh, Jasemidan Taleghani, 2015).

\section{Merasakan perlu tenaga yang besar dan kerjasama saat merawat lansia}

Pada saat merawat lansia yang tinggal di panti memerlukan perawatan yang lama dan butuh perhatian penuh, hal ini berkaitan dengan kondisi lansia yang mengalami penurunan terhadap kemampuan perawatan dirinya, karena faktor usia atau penyakit yang dideritanya. Pada saat merawat lansia, caregiver juga mmebutuhkan tenaga yang besar, yang diperlukan saat memandikan, membantu BAB dan BAK.

Kurangnya kemampuan dapat mengganggu kesehatan dan meningkatkan tekanan pada caregiver. Caregiver berada di bawah risiko tinggi untuk mengalami beberapa masalah kesehatan, seperti tingkat kecemasan tinggi (Schulz et al., 1995), depresi (Livingston et al., 1996), dan keluhan fisik dapat menyebabkan meningkatnya kematian (Rezende et al, 2009).

\section{Merasakan perilaku dan keinginan lansia yang semaunya sendiri}

Tema merasakan perilaku dan keinginan lansia yang semaunya sendiri menjawab tujuan penelitian mengeksplorasi hambatan yang dialami partisipan yang merawat lansia dengan defisit perawatan diri. Merasakan perlu tenaga yang besar dan kerjasama saat merawat lansia adalah hasil akhir dari hambatan yang dialami partisipan yaitu perubahan kondisi lansia.

Penelitian Tseng CN, et. al (2015) mengungkapkan bahwa caregiver menggambarkan bagaimana mereka mencoba untuk mengatasi masalah pasien dengan inkontinensia dengan belajar dan membuat penyesuaian sikap untuk mengatasi masalah mereka. Secara khusus, mereka sering mencoba untuk mengembangkan sikap yang lebih positif terhadap situasi mereka.Caregiver tidak hanya menggambarkan bagaimana mereka melakukan yang terbaik untuk merawat pasien tetapi juga bagaimana mereka menyesuaikan sikap mereka untuk menerima situasi dan melanjutkan perawatan.Sikap penyesuaian dilakukan caregiver untuk menerima dan menghargai lansia, sehingga tetap dapat memberikan perawatan yang efektif.

\section{Keinginan merawat lansia yang lebih baik dan lebih sabar lagi}

Tema kesembilan dari penelitian ini adalah keinginan merawat lansia yang lebih baik dan lebih sabar lagi saat merawat lansia yang merupakan harapan caregiver saat merawat lansia dengan defisit perawatan diri. Akibat dari ketergantungan lansia terhadap caregiver, muncul keadaan yaitu caregiver role strain atau ketegangan fungsi peran 
sebagai caregiver. Keadaan ini berdampak pada kehidupancaregiver antara lain beresiko kehilangan kehidupan sosial dengan tidak dapat lagi berhubungan dengan temanteman dan kerabat karena tidak ada waktu untuk melakukan sosialisasi. Merawat lansia juga menimbulkan masalah fisik dan psikologis, sehingga bisa menimbulkan stress. Untuk mengatasi ini maka diperlukan kesabaran dalam merawat lansia.

Menurut Hermanns dan Smith (2012), salah satu karakter yang diperlukan caregiver yang paling sering diidentifikasi adalah komitmen caregiver untuk membuat orang yang mereka rawat dapat menerima perawatan yang lebih baik.Respon psikologis caregiver bervariasi, tetapi berpusat pada keinginan mereka: keinginan untuk membuat perbedaan, mengurangi rasa sakit dan penderitaan dan membuat hal-hal yang lebih baik, untuk tujuan peningkatan kualitas hidup. Kesabaran adalah tema yang disampaikan oleh semua peserta dalam pemenuhan peran caregiveran.

\section{Terpanggil untuk merawat lansia seperti orang tua sendiri}

Tema kesepuluh dari penelitian ini adalah terpanggil untuk merawat lansia seperti orang tua sendiri saat merawat lansia yang

\section{DAFTAR PUSTAKA}

Andini, Ayu dan Supriyadi. 2013. Hubungan antara berpikir positif dengan harga diri pada lansia yang tinggal di panti jompo di Bali. Jurnal Psikologi Udayana. Vol. 1 No.1: 129-137.

Fitria, N. 2009, Prinsip Dasar dan Aplikasi Penulisan Laporan Pendahuluan dan merupakan makna caregiver saat merawat lansia dengan defisit perawatan diri.

Caregiver merupakan bagian dari perawatan yang penting dalam mendukung lansia dalam perawatan diri mereka. Dukungan, motivasi dan pengetahuan tentang kiat dalam perawatan merupakan hal yang penting perawatan diri dan memfasilitasi hubungan caregiver dan lansia dalam kemampuan perawatan diri dalam aktivitas perawatan diri (Söderhamn et.al, 2011).

\section{SIMPULAN}

Dari hasil penelitian ini didapatkan kesimpulan bahwa caregiver merupakan bagian dari perawatan yang penting dalam mendukung lansia dalam perawatan diri mereka. Dukungan, motivasi dan pengetahuan tentang kiat dalam perawatan merupakan hal yang penting dalam perawatan diri dan memfasilitasi hubungan caregiver dan lansia dalam kemampuan perawatan diri dalam aktivitas perawatan diri.

Hasil penelitian ini dapat dijadikan rujukan bagi perawat bahwa sebenarnya caregiver juga memiliki potensi untuk memberikan bantuan perawatan, tetapi mereka tetap memerlukan bimbingan dan dukungan perawat geriatri yang mempunyai dasar keilmuan tentang keperawatan pada geriatri.

Strategi Pelaksanaan Tindakan Keperawatan. Jakarta : Salemba Medika Gilbert P., (2010). The Compassionate Mind: A New Approach to Life's Challenges. Constable, London.

Hermanns, M., \& Smith, B.M., (2012). Caregiving:

A Qualitative Concept Analysis. The Qualitative Report 2012 Volume 17, Article 
75, 1-18 http://www.nova.edu/ssss/QR/QR17/ hermanns. pdf

Lecovich E, 2008. Caregiving burden, community services, and quality of life of primary Caregivers of frail elderly persons. Journal of Applied Gerontology, 27: 309-330.

Losada A, Pérez-Peñaranda A, RodriguezSanchez E, Gomez-Marcos MA, Ballesteros-Rios C, Ramos-Carrera IR, Campodela TorreMA, García-Ortiz L, 2009. Leisure and distress in Caregivers for elderly patients. Archives of Gerontology and Geriatrics, 50: 347-50.

Nordenfelt, .2009. "The concept of dignity," in Dignity in Care for Older People, L. Nordenfelt, Ed., Wiley-Blackwell, West Sussex,UK.

Okoye UO., Asa SS. 2011. Caregiving and Stress: Experience of People Taking Care of Elderly Relations in South-eastern Nigeria. Arts and Social Sciences Journal, Volume 2011: ASSJ-29

Reuser M, Bonneux L, Willekens F. 2010. The effect of risk faktors on theduration of cognitive impairment:A multistate life table analysis ofthe U.S. Health and Retirement Survey. Netspar DiscussionPaper 01/2010-036

Syam'ani,. 2011. Studi Fenomenologi Tentang Pengalaman Meng-hadapi Perubahan Konsep Diri: Harga DiriRendah Pada lansia diKecamatan Jekan Raya Kota Palangkaraya:UI, Jakarta

Söderhamn O, Skisland A, Herrman M. 2011. Self-care and anticipated transition into retirement and later life in a Nordic welfare context.J Multidiscip Healthc.;4:273-279.

Tseng, C.N., Huang, G.S., Jui Yu P., Fang Lou, M., (2015). A Qualitative Study of Family Caregiver Experiences of Managing Incontinence in Stroke Survivors. Journals.plos.org/plosone/article? id=10.1371

Zamanzadeh, V., Jasemi, M., Taleghani, F. (2015). Effective Factors in Providing Holistic Care: A Qualitative Study. Journal Indian Palliatif Care. Doi: 10.4103/ 0973-1075.156506 